\title{
A rare case of primitive right atrium angio- sarcoma with favorable outcome, in a young female. Case report and literature review
}

\author{
Dan Radulescula, Sorin Pripon ${ }^{1 b}$, Letitia I Radulescu², \\ Nicolae A Constantea ${ }^{3 a}$, Iulia Gulei ${ }^{4 c}$.
}

Primary malignant cardiac tumors are extremely rare, but their associated mortality is very high. The clinical presentation is often variable and nonspecific; by the time symptoms appear, the tumor has usually evolved to a large intracardiac and paracardiac mass causing considerable hemodynamic involvement, regional invasion and distant dissemination. We report a 26 year-old female with a right atrium angiosarcoma with a surprisingly favorable outcome at 2 years follow-up after treatment with a combination of neoadjuvant chemotherapy and surgical resection. She presented with chest tightness, shortness of breath at effort, atypical chest pain, palpitations, asthenia, weight loss and profuse perspiration. Physical examination and imaging diagnostic procedures, identified a pericardial effusion and a pathologic cardiac mass. The diagnosis of a malignant angiosarcoma was suggested after computed tomography, transthoracic and transesophageal echocardiography. It was confirmed at surgery by a biopsy followed by histopathology and immunohistochemistry (Rev Méd Chile 2008; 136:1311-6 ).

(Key words: Chemotherapy, adjuvant; Echocardiography, transesophageal; Hemangiosarcoma; Heart neoplams; Pericardial effusion)

\section{Angiosarcoma primitivo de la aurícula derecha en una mujer joven, con respuesta favorable al tratamiento. Reporte de un caso y revisión de la literatura}

Los tumores cardíacos malignos son extremadamente raros y su mortalidad es muy alta. El cuadro clínico es variable e inespecífico: frecuentemente cuando aparecen síntomas ya existe una gran masa intracardíaca y paracardíaca que causa compromiso hemodinámico grave, además de invasión locorregional y diseminación a distancia. Comunicamos un caso especial de una mujer joven que tuvo una evolución sorprendentemente favorable después de un tratamiento combinado con quimioterapia neoadyuvante y resección quirúrgica. La paciente presentó opresión precordial, disnea de esfuerzo, dolor torácico atípico, palpitaciones, astenia, baja de peso y sudoración profusa. El examen físico y exámenes complementarios, especialmente de imágenes, identificaron un derrame pericárdico y una masa cardíaca patológica. La tomografía computada y la ecocardiografía, particularmente la transesofágica, sugirieron el diagnóstico de angiosarcoma maligno, que se confirmó en una intervención quirúrgica que incluyó una biopsia con estudios histopatológicos e inmunohistoquímicos. Se discuten las alternativas del diagnóstico y del tratamiento, y se revisan la epidemiología y los recursos terapéuticos actuales en la literatura. Este caso ilustra la utilidad de la ecocardiografía transesofágica, para el diagnóstico de estos tumores y se plantea que el uso de nuevas alternativas quimioterápicas asociadas a la extirpación quirúrgica pueden mejorar la sobrevida que, en nuestra paciente, alcanza dos años libre de síntomas.

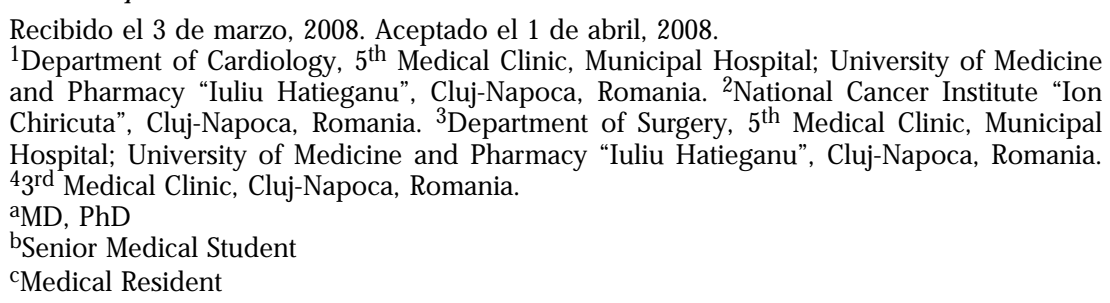

Corresponding author: Associate-Prof. Dr. Dan Radulescu, Cardiology Department, $5^{\text {th }}$ Medical Clinic, Municipal Hospital. Tabacarilor Street, Nr. 11, Cluj-Napoca, Romania, 400139 (postal code), 00-40-742-091830 (phone number), 00-40-264-438256 (fax), dr.radulescu_dan@yahoo.com (email). 
P rimary cardiac tumors (PCTs) are extremely rare, with a prevalence rate of $0.01 \%$ in collective autopsy studies ${ }^{1}$. The majority of them are benign, cardiac myxoma being the most common PCT. The malignant tumors of the heart account for only $25 \%{ }^{2}$ of PCTs and about $90 \%$ 95\% are sarcomas ${ }^{3}$ : angiosarcoma, rhabdomyosarcoma, pericardial mesothelioma, fibrosarcoma, lymphosarcoma, osteosarcoma or liposarcoma. Angiosarcoma of the heart is the most common primary malignant cardiac tumor ${ }^{1,4}$ and it carries a dismal prognosis 4 . The diagnosis if often delayed because of its non-specific clinical presentation. The tumor may remain clinically silent for a long time or cause a range of cardiac and systemic symptoms that mimic other diseases ${ }^{5-7}$. Symptoms are determined by its size and location ${ }^{4}$.

The preferred initial method for detecting cardiac tumors is conventional echocardiography, the primary diagnostic technique because of its high degree of accuracy, noninvasiveness and cost effectiveness ${ }^{4}$. Sometimes, using solely the transthoracic echocardiography, a complete assessment of the heart and surmounding tissue may be difficult; other complementary image techniques should be used to provide precise information on the extension of the tumor. By combining these diagnostic procedures, it is feasible to simultaneously evaluate the cardiac structures and the surrounding tissue and to determine the clinical and morphologic characteristics of the injured heart.

\section{CASE REPORT}

A 26 year-old woman was admitted to our clinic because she complained of chest tightness. She had presented for 8 months asthenia, loss of appetite, weight loss, atypical chest pain, palpitations, and profuse perspiration. She also noticed in the last 2 months dyspnea at effort. On admission the physical examination revealed no signs of cardiac failure at rest, regular pulse (108 beats/min), normal blood pressure (120/70 $\mathrm{mm} \mathrm{Hg})$, an enlarged heart and diminished cardiac sounds. An EKG revealed low voltage and flattened $\mathrm{T}$ waves in all leads. Erythrocyte sedimentation rate was $23 \mathrm{~mm} / \mathrm{h}, \mathrm{C}$ reactive protein was in normal range. A moderate microcytic hypochromic anemia was also present (hemoglobin $=9.5 \mathrm{~g} / \mathrm{dL})$ with minor leukocytosis $(10.300$ / $\mathrm{mm}^{3}$ ). Tests for rheumatoid factor and antinuclear antibodies (ANA) were negative; therefore a systemic disease was excluded. Hepatic and renal tests were within normal limits.

Chest X-rays documented a globally enlarged heart silhouette and moderate lung stasis (Figure 1). Two-dimensional transthoracic echocardiogra-

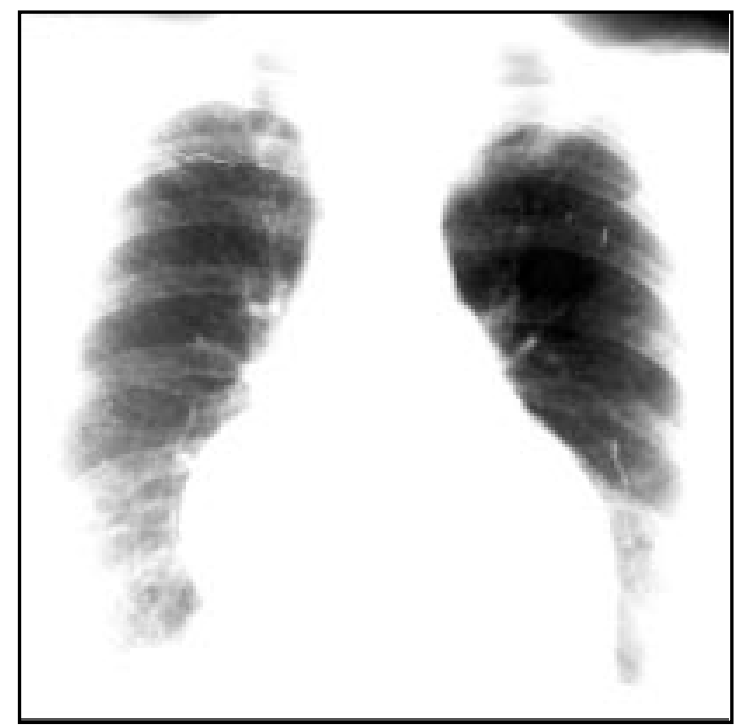

Figura 1. Chest radiograph: Globally enlarged heart silhouette and moderate lung stasis. 
phy confirmed the pericardial effusion revealing an echo- free space $(14 \mathrm{~mm}$ anterior, $24 \mathrm{~mm}$ posterior) but no signs of tamponade. Left ventricular ejection fraction was 51\% (Figure 2). Pericardiocentesis revealed a serous liquid containing a large number of lymphocytes, lactate dehydrogenase $(\mathrm{LDH}) 170 \mathrm{U}$, total protein $7.7 \mathrm{~g} / \mathrm{dL}$, glucose $64 \mathrm{mg} / \mathrm{dL}$ and no tumor cells. PPD tuberculosis

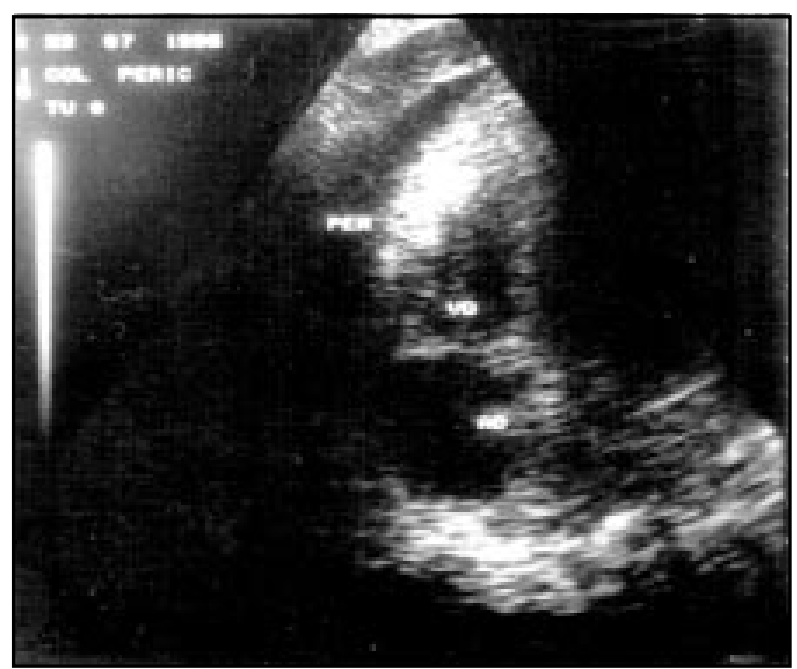

Figure 2. Two-dimensional transthoracic echocardiography: Pericardial effusion (echo- free space $14 \mathrm{~mm}$ anterior, $24 \mathrm{~mm}$ posterior).

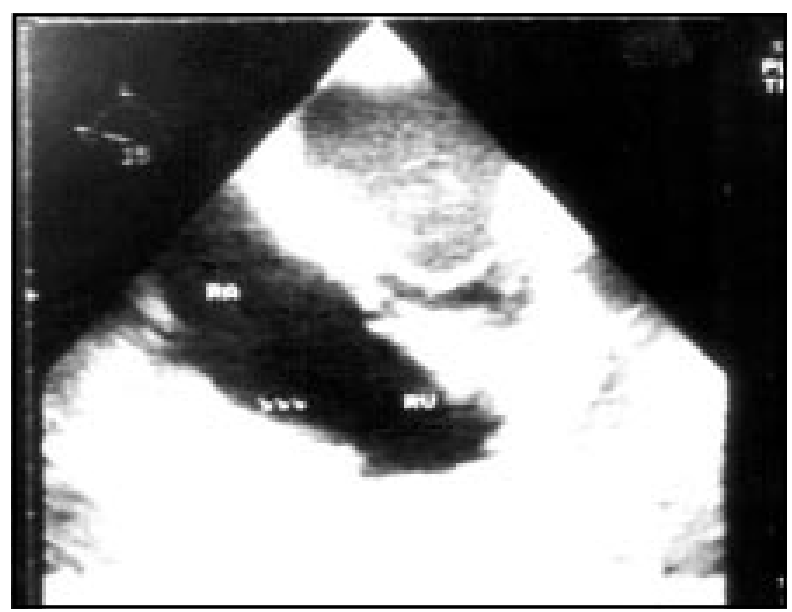

Figure 3. Transesophageal echocardiography: Pericardial effusion; right atrial echogenic mass, immobile, $4 \mathrm{~cm}$ in the longest diameter, invading the right atrium free wall. skin tests were negative. Transesophageal echocardiography (TEE) highlighted the pericardial effusion and revealed a right atrial echogenic mass, immobile, $4 \mathrm{~cm}$ in the longest diameter, invading the right atrium free wall (Figure 3 ). The CT scan showed the same moderate pericardial effusion and the right atrium mass invading the right atrium and the surrounding areas.

The patient was referred to the Department of Cardiac Surgery. The presence of the tumor was confirmed, but a complete resection was not possible because the tumor invaded the entire right atrial wall and extended to the tricuspid valve. Biopsy followed by histopathology examination showed a vascular structure infiltrating the myocardium, with spindle-shaped cells and pleomorphic nuclei. Immunohistochemistry was positive for CD 34 and vimentin. The final diagnosis was right atrium angiosarcoma.

A complete body CT scan documented no thorax invasion and the absence of metastasis. The patient underwent the ADIC (Adriamycin, DTIC) chemotherapy protocol: Epirubicin $75 \mathrm{mg} / \mathrm{m}^{2}$ on day 1 and Diticene $250 \mathrm{mg} / \mathrm{m}^{2}$ on days 1 to 5 . After the third chemotherapy cycle, a complete excision of the tumor with right atrial wall plastia was performed in the Department of Cardiac Surgery AKH, in Vienna, Austria. At 6 months after the intervention the patient had improved clinically, with no symptoms and the periodical TE echocardiography was normal. The patient is alive and asymptomatic 2 years after treatment.

\section{Discussion}

The particularity of our case consists in the young age and the sex (feminine) in whom we diagnosed a primary cardiac angiosarcoma. Another feature is the surprisingly favorable outcome after neoadjuvant chemotherapy and surgical resection, with survival free of symptoms after 2 years, while the literature reflects a discouraging prognosis in this disease. The benefit of modern chemotherapy in the treatment of these cases is still controver- 
sial, but new studies are expected to clear out the uncertainties.

Primitive cardiac neoplasms are very rare, with an incidence at autopsy ranging from $0.0017 \%$ to $0.033 \% 2,8$. Twenty-five percent of all PCTs are malignant and almost all of them are sarcomas. The prevalence of the right heart primitive sarcomas is dominated by angiosarcomas followed by rhabdomyosarcomas, fibrosarcomas, lymphosarcomas, osteosarcomas, liposarcomas. The angiosarcomas represent $7.3 \%$ of PCTs and they account for $30 \%$ of all primary cardiac malignant tumors. Their incidence is high in individuals with ages between 20 to 50 years, the mean patient age for angiosarcoma being 48 years (range, 10-76) ${ }^{9}$. The prevalence of angiosarcomas is 2-3 times higher in men than in women ${ }^{8,9}$. Cardiac sarcomas mainly involve the right heart, two-thirds of angiosarcomas being located in the right atrium, in contrast to myxomas, and rhabdomyosarcomas which are mostly located in the left cavities of the heart.

With the exception of mesotheliomas (where exposure to asbestos has been incriminated) the etiology of PCTs remains unknown. There may be a possible etiologic correlation between the HIV infection or Kaposi sarcoma and cardiac angiosarcomas $^{8}$. Cardiac angiosarcomas consist of malignant cells forming vascular channels. Immunophenotyping for peroxidase is positive for factor VIII. It is well documented that these tumors have a tendency for rapid growth, local invasion and dissemination; the distant metastasis are mainly located in the liver, bones, adrenal glands, central nervous system, lymphatic nodes, and lungs. In general, malignant PCTs, including angiosarcoma, may present with any cardiac symptom $^{5,6,10,11}$, but manifestations of heart failure and systemic embolism are the most common ones initially ${ }^{7,12}$. Pericardial effusions often accompany cardiac angiosarcomas ${ }^{13}$. The main complications are represented by pulmonary thromboembolism, right heart failure, cardiac tamponade, superior vena cava syndrome, sepsis, fistulas between cardiac cavities and coronary vasculature, cardiac perforation ${ }^{14-16}$. The differential diagnosis of these tumors is sometimes difficult. Sarcomas of the tricuspid and mitral valve may mimic cardiac angiosarcomas ${ }^{17,18}$.

Previously, most cardiac angiosarcomas were not diagnosed during life, but advances in image procedures like echocardiography, magnetic resonance imaging, computed tomography and especially transesophageal echocardiography have made it possible to diagnose these diseases in living patients. Nevertheless, it is quite difficult to highlight these malignant cardiac tumors with conventional diagnostic tools, especially with those non-invasive. Doppler echocardiography is the usual technique for the initial diagnosis, providing preliminary data. It has the obvious advantage of being a cheap and highly available tool that can be performed at any moment, at the patient's bedside with no contraindications. It can sometimes be difficult to clearly define the structures which have been invaded by the tumor. A benign tumor may also be erroneously diagnosed as angiosarcoma, because ultrasound images sometime resemble those of atrial myxoma ${ }^{19}$. Magnetic resonance imaging (MR) has the advantage of providing better quality images and a better appraisal of the density and extent of the tumor. It also allows precise characterization of invaded cardiac and paracardiac neighboring structures. Computed tomography is able to better define calcification, the study time is shorter and the procedure is essentially useful when MR is contraindicated. It also allows the diagnosis by means of guided transthoracic biopsies ${ }^{20}$.

The multiplane transesophageal echocardiography (TEE) is the investigation of choice to diagnose intracardiac tumors in most Cardiology Units in the world and it was of high diagnostic usefulness in our case as well. Different studies document a similar effectiveness for TEE in detecting both right and left atrial angiosarcomas ${ }^{21,22}$. This technique can be very useful in assessing small intra- or paracardiac tumors and documenting tumor recurrence. Therefore, although at present TEE is a major and valid tool in clinical practice, it suffers from several and intrinsic limitations in diagnostic accuracy. One of its limitations is the inability to assess the malignant or benign nature of the tumor (the MR imaging may be more useful in this respect) ${ }^{23}$. In most cases it does not provide sufficient decisive information in terms of a correct diagnosis of malignant tumors. In our case the cardiac tumor was quite immobile, heterogeneous, with a large base of implantation and invasive, aspects suggesting a malignant character. A Cardio-MR or a CT scan 
allow a more accurate definition and even a precise characterization of cardiac tissue.

The elective treatment of cardiac angiosarcoma consists in radical ablation. A total body CT scan is compulsory before the intervention to determine local extension and to exclude possible metastasis. Heart transplantation may be of help in cases of unresectable tumors or tumor recurrence, unless distant metastasis are present $^{24}$. Surgical resection is essentially palliative; in less than $50 \%$ of patients a complete resection is possible, their mean survival rate being 24 months. The majority of patients have a very poor prognosis: most patients die within 1 year after the diagnosis 25 , with a 9-month median survival. Complete excision is correlated with increased survival ${ }^{4}$.

\section{REFERENCES}

1. Amonkar GP, Deshpande JR. Cardiac angiosarcoma. Cardiovasc Pathol 2006; 15: 57-8.

2. SilvERMAN NA. Primary cardiac tumor. Ann Surg 1980; 191: 127-38.

3. RoBerts WC. Primary and secondary neoplasms of the heart. Am J Cardiol 1997; 80: 671-82.

4. Brandt RR, Arnold R, Bohle RM, Dil T, Hamm CW. Cardiac angiosarcoma: case report and review of the literature. Z Kardiol 2005; 94: 824-8.

5. REYNEN K. Frequency of primary tumors of the heart. Am J Cardiol 1996; 77: 107.

6. Sarjeant JM, Butany J, Cusimano RJ. Cancer of the heart. Epidemiology and management of primary tumors and metastases. Am J Cardiovasc Drugs 2003; 3: 407-21.

7. Grande AM, Ragni T, Vigano M. Primary cardiac tumors. A clinical experience of 12 years. Tex Heart Inst J 1993; 20: 223-30.

8. Butany J, Yu W. Cardiac angiosarcoma: two cases and a review of the literature. Can J Cardiol 2000; 16: 197-205.

9. Janigan DT, Husain A, Robinson NA. Cardiac angiosarcomas. A review and a case report. Cancer 1986; 57: 852-9.

10. ABAD C. Cardiac tumors (II). Malignant primary tumors. Metastatic tumors. Carcinoid tumor. Rev Esp Cardiol 1998; 51: 103-14.

11. Roldán Torres I, Martí Bonmatí L, Peláez Gonzalez A. Cardiac tumor mimicking hypertrophic cardiomyopathy. Rev Esp Cardiol 2003; 56: 734.
The role of adjuvant therapy (radiation, chemotherapy) is still controversial. While some authors reported that conventional postoperative chemotherapy does not appear to modify the clinical course, other studies have shown that a combined surgical and adjuvant therapy is effective ${ }^{26}$. Chemotherapy may be of help not only in advanced cases with metastasis, but also as an adjuvant treatment before and after the resection. The survival may be prolonged by using new combinations of cytostatic drugs like Epirubicin, Diticene, Ifosfamide, Etoposide.

This case presentation underlines the value of TE echocardiography and other image procedures in diagnosing cardiac tumors. The observation also reflects the benefit brought by some new chemotherapy protocols in the treatment of cardiac angiosarcomas.

12. Perchinsky MJ, Luchtenstein SV, Tyers GF. Primary cardiac tumors: forty years' experience with 71 patients. Cancer 1997; 79: 1809-15.

13. Ananthasubramaniam K, Farha A. Primary right atrial angiosarcoma mimicking acute pericarditis, pulmonary embolism, and tricuspid stenosis. Heart 1999; 81: $556-8$.

14. Bishop WT, Chan NH, MacDonald IL, Tutassaura H. Malignant primary cardiac tumour presenting as superior vena cava obstruction syndrome. Can J Cardiol 1990; 6: 259-61.

15. Delgado Jiménez J, Tascón Pérez J, Albarrán González A, Ugarte J, Gómez Pajuelo C et al. Right comonary artery-right atrium fistula in primary angiosarcoma of the heart. Chest 1992; 10: 1629-30.

16. Sultan A, Amour A, Khan S. Cardiac angiosarcoma presenting with death due to cardiac perforation. $\mathrm{Br}$ J Cardiol 2006; 13: 213-5.

17. Forker EL, January LE, LAwrence MS. Primary sarcoma of the mitral valve. Am Heart J 1963; 66: 243-7.

18. Domanski MJ, Delaney TF, Kieiner DE, Goswitz M, Agatston A, Tucker E et al. Primary sarcoma of the heart causing mitral stenosis. Am J Cardiol 1990; 66: 893-5.

19. Hasegana T, Nakagana S, Chino M, Kunihiro T, Ui S, KIMURA M. Primary cardiac sarcoma mimicking benign myxoma: a case report. J Cardiol 2002; 39: 321-5.

20. Chiles C, Woodard PK, GutiérRez FR, Link KM. Metastatic involvement of the heart and pericardium: CT and MR imaging. Radiographics 2001; 21: 439-49. 
21. Engberding R, Daniel WG, Erbel R, Kasper W, Lestuzzi C, Curtius JM et AL. Diagnosis of heart tumours by transoesophageal echocardiography: a multicentre study in 154 patients. European Cooperative Study Group. Eur Heart J 1993; 14: 1223-8.

22. Fossati F, Tribouiloy C, Leborgne L, Boey S, Mirode A, Choquet D ET AL. Contribution of transesophageal echocardiography in the diagnosis of intraand para-cardiac masses. Arch Mal Coeur Vaiss 1993; 86: 331-8.

23. Sparrow PJ, KuRian JB, Jones TR, Sivananthan MU. MR imaging of cardiac tumors. Radiographics 2005; 25 : 1255-76.

24. Crespo MG, Pulpón LA, Pradas G, Serrano S, Segovia J, VEGAZO I ET AL. Heart transplantation for cardiac angiosarcoma: should its indication be questioned?J Heart Lung Transplant 1993; 12: 527-30.

25. Burke AP, Cowan D, Virmani R. Primary sarcomas of the heart. Cancer 1992; 69: 387-95.

26. Percy RF, Perryman RA, Amornmarn R, Lammert N, ConetTa DA, Bass TA ET al. Prolonged survival in a patient with primary angiosarcoma of the heart. Am Heart J 1987; 113: 1228-30. 